\title{
Flexural Bond Behavior of Rebar in Ultra-High Performance Concrete Beams Considering Lap-Splice Length and Cover Depth
}

\author{
Seongjun Kim, Jungwoo Lee, Changbin Joh, Imjong Kwahk* \\ Korea Institute of Civil Engineering and Building Technology, Goyang, South Korea \\ Email: seongjun@kict.re.kr, duckhawk@kict.re.kr, cjoh@kict.re.kr, "kwakim@kict.re.kr
}

Received 5 February 2016; accepted 20 March 2016; published 23 March 2016

Copyright (C) 2016 by authors and Scientific Research Publishing Inc.

This work is licensed under the Creative Commons Attribution International License (CC BY).

http://creativecommons.org/licenses/by/4.0/

(c) (i)

\section{Abstract}

This study intends to find out the correlation between the cover depth and the bond characteristics of UHPC through pull-out tests of UHPC specimens with different cover depths and bond tests of rebar using flexural members. In this experimental study, specimens are fabricated with the lap-splice length as test variable in relation with the calculation of the lap-splice length for 180MPa UHPC. Moreover, specimens are also fabricated with the cover depth as test variable to evaluate the effect of the cover depth on the UHPC flexural members. The load-displacement curves are analyzed for each of these test variables to compute the lap-splice length proposed in the K-UHPC structural design guideline and to evaluate the influence of the cover depth on the flexural members. As a result, the stability of the structural behavior can be significantly enhanced by increasing slightly the cover depth specification of the current UHPC Structure Design Guideline from the maximum value between 1.5 times of rebar diameter and $20 \mathrm{~mm}$ to the maximum value between 1.5 times of rebar diameter and $25 \mathrm{~mm}$.

\section{Keywords}

Bond Behavior, Ultra High Performance Concrete (UHPC), Lap-Splice Length, Cover Depth, Flexural Bond Test, Full-Out Test

\section{Introduction}

Ultra-high performance concrete (UHPC) was developed to provide superior structural and durable perfor-

"Corresponding author.

How to cite this paper: Kim, S., Lee, J., Joh, C. and Kwahk, I. (2016) Flexural Bond Behavior of Rebar in Ultra-High Performance Concrete Beams Considering Lap-Splice Length and Cover Depth. Engineering, 8, 116-129.

http://dx.doi.org/10.4236/eng.2016.83013 
mances like material strength of concrete, resistance to chloride and water permeability following the everincreasing enlargement in length and height of the structures. UHPC develops high compressive strength by modifying the constitutive materials, mix proportions and curing conditions and exhibits improved tensile strength by the admixing of steel fiber. This means that, unlike conventional concrete, the existing structure design codes cannot reflect the characteristics of UHPC [1]. Accordingly, studies are performed on the various behavioral characteristics of UHPC for its application in real structures [2]-[6]. The Korea Institute of Civil Engineering and Building Technology (KICT) developed the K-UHPC and published a dedicated structural design guideline based upon a series of experiments and analyses [7], which made it possible to design economical sections exploiting the outstanding material performance of UHPC.

For members made of normal strength concrete, the bond characteristics between the rebar and concrete are well-known through numerous studies since the efficient transmission of the tensile forces and the control of crack by the rebar is a critical matter in the design [7]-[13]. Besides, diversified studies were conducted to reflect appropriately the outstanding bond performance and tensile strength of UHPC in the design [2] [3] [5] [6] [14] [15].

Recalling that the rebar lap-splice length is inversely proportional to the square-root of the compressive strength of concrete, the minimum lap-splice length shortens for the rebar installed in UHPC because of its high compressive strength. This makes the calculation of the lap-splice length proposed by the current Structural Concrete Design Code inapplicable for UHPC [3] [7]. Accordingly, need is to suggest a design method for the lap-splice length fitted to the characteristics of UHPC. In addition, the required minimum concrete cover depth should also be calculated by another approach due to the dense structure of UHPC and its remarkable bond performance. In Japan, the minimum cover depth of UHPC is limited to 1.5 times the diameter of the rebar, which is significantly smaller than in normal concrete and increases the risk of splitting to occur along the flexuraltensile rebar at the bottom of the UHPC flexural member. This implies that adequate minimum cover depth must be suggested in the design guideline to secure the structural stability [16].

Accordingly, this study intends to find out the correlation between the cover depth and the bond characteristics of UHPC through pull-out tests of UHPC specimens with different cover depths and bond tests of rebar using flexural members. In this experimental study, specimens are fabricated with the lap-splice length as test variable in relation with the calculation of the lap-splice length for 180-MPa UHPC. Moreover, specimens are also fabricated with the cover depth as test variable to evaluate the effect of the cover depth on the UHPC flexural members. The load-displacement curves are analyzed for each of these test variables to compute the lap-splice length proposed in the K-UHPC structural design guideline and to evaluate the influence of the cover depth on the flexural members.

\section{Test Method and Setting of Test Variables}

\subsection{Selection of Test Variables}

Concrete develops higher bond performance as much as it is reinforced by fiber or its tensile strength is high. Equation (1) expressing the formula for the computation of the lap-splice length proposed by the current Structural Concrete Design Code cannot be applied for high performance or high strength concretes like UHPC.

$$
l_{d b}=\frac{0.6 d_{b} f_{y}}{\sqrt{f_{c k}}}
$$

where $l_{d b}=$ basic lap-splice length $(\mathrm{mm}) ; d_{b}=$ nominal diameter of rebar, steel wire or prestressing steel strand $(\mathrm{mm}) ; f_{y}=$ design yield strength of rebar (MPa); and, $f_{c k}=$ design compressive strength of concrete (MPa).

In the Structural Concrete Design Code, Equation (1) limits the effect of the compressive strength of concrete to $70 \mathrm{MPa}$, which is obviously inappropriate to reflect the bond performance of UHPC. Kook et al. [3] proposed the following design formula for the minimum lap-splice length of the rebar based upon on an experimental study evaluating the bond performance of UHPC.

$$
l_{d b}=\frac{0.075 d_{b} f_{y}}{\sqrt{f_{c k}}}
$$


The experimental results of Kook et al. revealed that sufficient bond performance could be achieved when the bond length was $2 d_{s}$ using a 400-MPa rebar. According to Equation (2), a minimum lap-splice length of about $2.2 d_{s}$ is required for $400-\mathrm{MPa}$ deformed rebar in the case of 180-MPa UHPC. Figure 1 compares the lapsplice lengths according to the diameter of the deformed rebar based on the formulae proposed by the Structural Concrete Design Code and former studies.

The minimum lap-splice length prescribed by the current Design Guideline of UHPC is seen to provide sufficient safety margin. Besides, pull-out test is also carried out to observe the effect of the cover depth. With reference to the specifications proposed by RILEM, the specimens were fabricated with length of $100 \mathrm{~mm}$ (D10), $150 \mathrm{~mm}$ (D13, D16), and $200 \mathrm{~mm}$ (D19, D22) according to the rebar diameter and bond test specimens with bond lengths 1.0, 1.5, 2.0 and 3.0 times the diameter of the rebar were fabricated. Table 1 arranges each variable related to the bond specimens and the pull-out test plan.

The K-UHPC flexural members adopt thinner cover depth than the members made of normal concrete. Such condition is likely to be unfavorable in term of the bond of the rebar in case of flexural deformation. Accordingly, it would be recommendable to assess the appropriateness of the lap-splice length considering the flexural bond characteristics of the rebar in flexural members in addition to the results of the pull-out test. This approach analyzing additionally the flexural bond characteristics has been widely adopted in previous studies related to normal strength concrete or high strength concrete [17]-[20].

For the evaluation of the flexural bond characteristics of UHPC, a total of 19 specimens were fabricated considering the rebar diameter $\left(d_{b}\right)$, the cover depth ratio $\left(c / d_{b}\right)$, and the splice length ratio $\left(l_{s} / d_{b}\right)$ as test variables. The considered rebar diameters are 19 and $25 \mathrm{~mm}$. The minimum cover depth is set to $1.5,2.0$ and 3.0 times the rebar diameter as proposed in the K-UHPC Structure Design Guideline. The lap-splice length is set to 2.2, 3.0 and 4.0 times the rebar diameter as well as to 5.5 times the rebar diameter as suggested in the Guideline. The design compressive strength of UHPC being $180 \mathrm{MPa}$, the strength measured at 28 days was applied as the strength of the specimens. Table 2 lists the characteristics per type of specimen with respect to the test variables chosen for the flexural bond test.

\subsection{Mix Proportions and Fabrication of K-UHPC}

Table 3 presents the mix proportions of UHPC applied for the evaluation of the bond characteristics. The waterto-binder ratio (W/B) is 0.2 . Silica fume with specific surface area of $200,000 \mathrm{~g} / \mathrm{m}^{2}$ and $\mathrm{SiO}_{2}$ content larger than $96 \%$ is adopted as reactive powder. Polycarbonate superplasticizer in liquid form is used. Steel fiber with tensile strength of $2500 \mathrm{MPa}$, diameter of $0.2 \mathrm{~mm}$ and length of $13 \mathrm{~mm}$ is admixed in $2 \%$ volume fraction. Bars with grade of $400 \mathrm{MPa}$ and diameter of 13 and $19 \mathrm{~mm}$ are used to reinforce UHPC. It was used for K-UHPC (180 $\mathrm{MPa}$ ) developed by the Korea Institute of Civil Engineering and Building Technology.

The UHPC with the mix proportions of Table 3 was placed and subject to wet curing at room temperature during about 24 hours immediately after placing. Then, UHPC was completed by steam curing at $90^{\circ} \mathrm{C}$ during 2

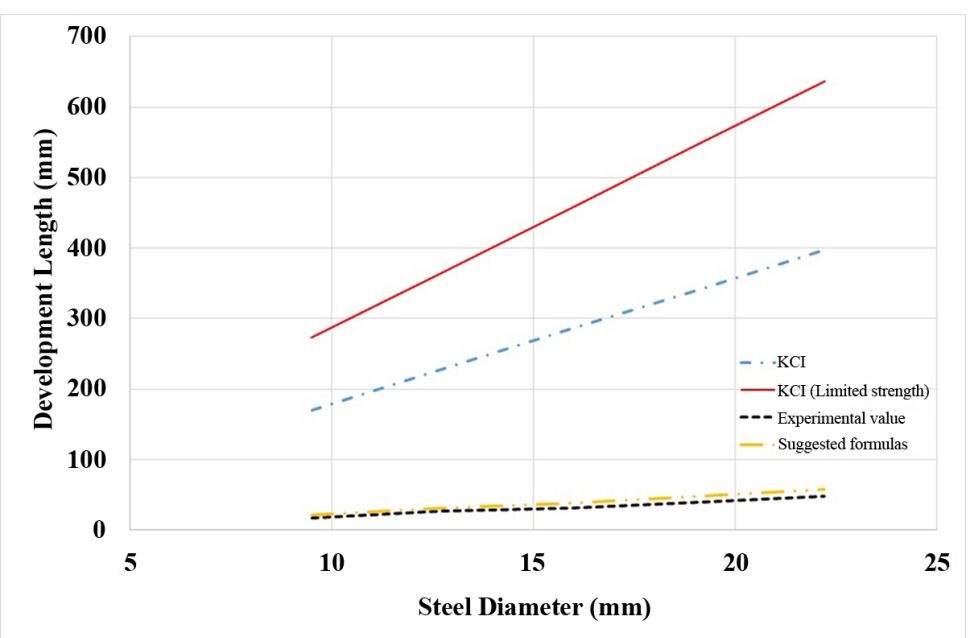

Figure 1. Comparison of lap-splice lengths with respect to diameter of rebar. 
Table 1. Plan of pull-out test.

\begin{tabular}{|c|c|c|c|c|c|}
\hline Steel rebar & $\begin{array}{l}\text { Bond length } \\
\text { (mm) }\end{array}$ & $\begin{array}{l}\text { Concrete } \\
\text { cover }(\mathrm{mm})\end{array}$ & Steel rebar & $\begin{array}{l}\text { Bond length } \\
\text { (mm) }\end{array}$ & $\begin{array}{c}\text { Concrete } \\
\text { cover }(\mathrm{mm})\end{array}$ \\
\hline \multirow{13}{*}{$\begin{array}{c}\mathrm{D} 10 \\
(9.5 \mathrm{~mm})\end{array}$} & & & \multirow{13}{*}{$\begin{array}{c}\text { D19 } \\
(19.1 \mathrm{~mm})\end{array}$} & 19.1 & 19.1 \\
\hline & & & & 19.1 & 38.2 \\
\hline & & & & 19.1 & 65.5 \\
\hline & 9.5 & 9.5 & & 19.1 & 65.5 \\
\hline & 9.5 & 19 & & 19.1 & 90 \\
\hline & 9.5 & 45 & & 28.65 & 65.5 \\
\hline & 19 & 19 & & 28.65 & 65.5 \\
\hline & 28.5 & 9.5 & & 38.2 & 38.1 \\
\hline & 28.5 & 19 & & 38.2 & 65.5 \\
\hline & \multirow[t]{4}{*}{28.5} & 45 & & 38.2 & 65.5 \\
\hline & & & & 57.3 & 19.1 \\
\hline & & & & 57.3 & 38.2 \\
\hline & & & & 57.3 & 90 \\
\hline \multirow{10}{*}{$\begin{array}{c}\mathrm{D} 13 \\
(12.7 \mathrm{~mm})\end{array}$} & 12.7 & 12.7 & \multirow{17}{*}{$\begin{array}{c}\mathrm{D} 22 \\
(22.2 \mathrm{~mm})\end{array}$} & & \\
\hline & 12.7 & 25.4 & & & \\
\hline & 12.7 & 69 & & 22.2 & 22.2 \\
\hline & 19.05 & 69 & & 22.2 & 44.4 \\
\hline & 25.4 & 69 & & 22.2 & 89 \\
\hline & 25.4 & 69 & & 44.4 & 44.4 \\
\hline & 25.4 & 25.4 & & 66.6 & 22.2 \\
\hline & 38.1 & 12.7 & & 66.6 & 44.4 \\
\hline & 38.1 & 25.4 & & & \\
\hline & 38.1 & 69 & & & \\
\hline \multirow{7}{*}{$\begin{array}{c}\mathrm{D} 16 \\
(15.9 \mathrm{~mm})\end{array}$} & 15.9 & 15.9 & & & \\
\hline & 15.9 & 31.8 & & & \\
\hline & 15.9 & 67 & & & \\
\hline & 31.8 & 31.8 & & & \\
\hline & 47.7 & 15.9 & & & \\
\hline & 47.7 & 31.8 & & & \\
\hline & 47.7 & 67 & & & \\
\hline
\end{tabular}

Table 2. Properties of flexural specimens.

\begin{tabular}{|c|c|c|c|c|}
\hline Case & $\begin{array}{l}\text { Splice length } \\
\text { ratio }\left(l_{s} / d_{b}\right)\end{array}$ & $\begin{array}{l}\text { Cross-sectional } \\
\text { dimensions, } \\
b \times h \quad(\mathrm{~mm})\end{array}$ & $\begin{array}{l}\text { Cover depth ratio } \\
\qquad\left(c / d_{b}\right)\end{array}$ & $\begin{array}{l}\text { Concrete } \\
\text { strength, } f_{c k} \\
\text { (MPa) }\end{array}$ \\
\hline $\begin{array}{c}\text { D13-L3-CR } \\
\text { D13-L4-CR } \\
\text { D13-LC1-CR }\end{array}$ & $\begin{array}{l}3.0(38.1 \mathrm{~mm}) \\
4.0(50.8 \mathrm{~mm}) \\
2.2(29.5 \mathrm{~mm})\end{array}$ & $200 \times 300$ & $\begin{array}{c}1.5 \\
(20.0 \mathrm{~mm})\end{array}$ & \\
\hline $\begin{array}{c}\text { D13-L4-C2 } \\
\text { D13-LC2-C2 } \\
\text { D13-LC1-C2 }\end{array}$ & $\begin{array}{l}4.0(50.8 \mathrm{~mm}) \\
5.5(73.2 \mathrm{~mm}) \\
2.2(29.5 \mathrm{~mm})\end{array}$ & $200 \times 305.4$ & $\begin{array}{c}2.0 \\
(25.4 \mathrm{~mm})\end{array}$ & \\
\hline $\begin{array}{c}\text { D13-L3-C3 } \\
\text { D13-L4-C3 } \\
\text { D13-LC2-C3 } \\
\text { D13-LC1-C3 }\end{array}$ & $\begin{array}{l}3.0(38.1 \mathrm{~mm}) \\
4.0(50.8 \mathrm{~mm}) \\
5.5(73.2 \mathrm{~mm}) \\
2.2(29.5 \mathrm{~mm})\end{array}$ & $210 \times 318.1$ & $\begin{array}{c}3.0 \\
(38.1 \mathrm{~mm})\end{array}$ & 18 \\
\hline $\begin{array}{c}\text { D19-L3-CR } \\
\text { D19-L4-CR } \\
\text { D19-LC1-CR }\end{array}$ & $\begin{array}{l}3.0(57.3 \mathrm{~mm}) \\
4.0(76.4 \mathrm{~mm}) \\
2.2(44.4 \mathrm{~mm})\end{array}$ & $240 \times 324$ & $\begin{array}{c}1.5 \\
(28.7 \mathrm{~mm})\end{array}$ & \\
\hline $\begin{array}{c}\text { D19-L3-C2 } \\
\text { D19-L4-C2 } \\
\text { D19-LC1-C2 }\end{array}$ & $\begin{array}{l}3.0(57.3 \mathrm{~mm}) \\
4.0(76.4 \mathrm{~mm}) \\
2.2(44.4 \mathrm{~mm})\end{array}$ & $260 \times 333.6$ & $\begin{array}{c}2.0 \\
(38.2 \mathrm{~mm})\end{array}$ & \\
\hline $\begin{array}{l}\text { D19-L4-C3 } \\
\text { D19-LC1-C3 }\end{array}$ & $\begin{array}{l}4.0(76.4 \mathrm{~mm}) \\
2.2(44.4 \mathrm{~mm})\end{array}$ & $290 \times 352.7$ & $\begin{array}{c}3.0 \\
(57.3 \mathrm{~mm})\end{array}$ & \\
\hline
\end{tabular}

Note: CR = cover depth $\left(1.5 d_{s}\right)$; C2 = cover depth $\left(2.0 d_{s}\right)$; C3 = cover depth (3.0 $\left.d_{s}\right)$; LC1 = splice length $(2.2$ $\left.d_{s}\right)$; LC2 = splice length (5.5 $\left.d_{s}\right)$; LC3 = splice length $\left(3.0 d_{s}\right)$; L4 = splice length $\left(4.0 d_{s}\right)$. 
Table 3. Mix proportions of UHPC.

\begin{tabular}{ccccccc}
\hline W/B & Cement & Silica fume & Sand & Filler & Superplasticizer & Steel fiber \\
\hline 0.2 & 1.0 & 0.25 & 1.1 & 0.3 & 0.016 & $2 \%$ \\
\hline
\end{tabular}

to 3 days. The physical properties of UHPC are listed in Table 2. The compressive strength and tensile strength were found to be $180 \mathrm{MPa}$ and $12 \mathrm{MPa}$ through compressive strength test and direct tensile test.

\subsection{Installation and Testing Method of Rebar Pull-Out Test Specimens}

Pull-out test of the rebar was performed according to the method suggested by RILEM and considering the specificity of K-UHPC [21]. Note that the bond length of 5.0 times the rebar diameter $\left(5.0 d_{s}\right.$ ) prescribed by RILEM refers to ordinary concrete. A previous experimental study applied a bond length of $5.0 d_{s}$ but the final bond performance could not be verified because of the rebar yielded before bond failure. Here, pull-out test is performed to determine the minimum cover depth and the minimum bond length of the deformed bar in K-UHPC. To that goal, cubic specimens were fabricated using K-UHPC with design compressive strength of $180 \mathrm{MPa}$. D10, D13, D16, D19, D22 were embedded in the specimens with lengths corresponding to 1.5, 2.0 and 3.0 times the diameter of the rebar. Figure 2 presents the specimens and the pull-out test using a 100-ton UTM.

\subsection{Installation and Testing Method of Flexural Bond Test Specimens}

Lee et al. [20] utilized a cantilevered flexural member to evaluate the flexural bond behavior characteristics of the rebar. However, considering the 180-MPa strength of UHPC, this study applies the method adopted by Jung et al. [19] with partial modification. Figure 3 shows the fabricated specimen in which the deformed bar is arranged in the tensile zone to assess the anchoring capacity and the relation between the displacement and the ductility according to the change in the cover depth with different lap-splice lengths. The cover depth, $c$, on the lateral and top faces of the lap splice is increased regularly to 1.0, 2.0 and 3.0 times the diameter of the rebar.

In the Structural Concrete Design Code, the formula computing the lap-splice length limits the effect of the compressive strength of concrete to $70 \mathrm{MPa}$ and is thus inappropriate to reflect the bond performance of K-UHPC. Accordingly, the minimum lap-splice length corresponding to 5.5 times the rebar diameter proposed in the K-UHPC Structure Design Guideline together with shorter lengths of 2.2, 3.0 and 4.0 times the rebar diameter are chosen for the lap-splice lengths of the flexural members. The consideration of various lap-splice lengths was dictated by the will to evaluate the effect of the concrete cover depth when adopting identical lap-splice length.

A displacement control-type 200-ton actuator manufactured for the test was used to apply the load and for the measurement. As shown in Figure 4, the displacement of the specimen was measured by means of a LVDT installed below the loading zone and strain gauges were attached on the loaded zone to measure the strain of the reinforcing bars. LVDTs were also disposed at the free end to measure the slip between the bars and concrete. Figure 5 shows the before and after flexural test specimen.

\section{Test Results and Analysis}

\subsection{Analysis of Pull-Out Test Results}

Pull-out test was performed to evaluate the bond characteristics between K-UHPC and the rebar. Table 4 arranges the test results. It can be seen that the bond behavior varies according to the bond length and that the bond stress shows different distribution with respect to the rebar length. The average bond stress $(u)$ between the rebar and concrete is computed by Equation (3) using the stress $\left(f_{s}\right)$ developed in the rebar during loading or using the applied load $(P)$ divided by the bond area.

$$
u=\frac{A_{b} f_{s}}{\pi d_{b} l_{s}}=\frac{P}{\pi d_{b} l_{s}}(\mathrm{MPa})
$$

where $A_{b}=$ cross-sectional area of rebar $\left(\mathrm{mm}^{2}\right) ; f_{s}=$ stress developed in rebar during loading (MPa); $d_{b}=$ diameter of rebar (mm); and, $l_{s}=$ bond length $(\mathrm{mm})$. 


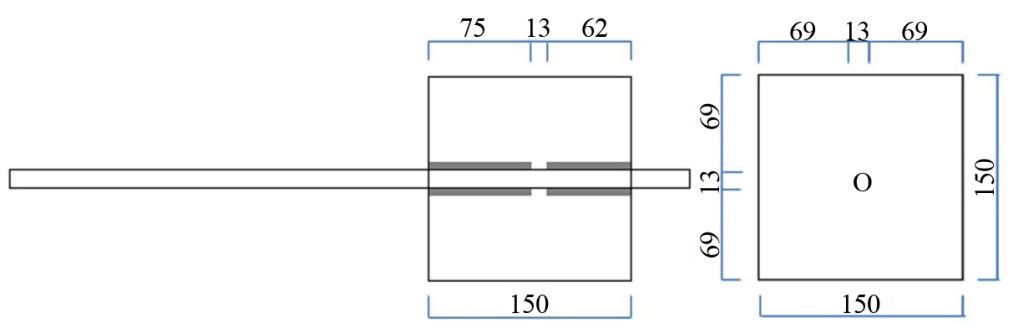

(a) Details of specimen

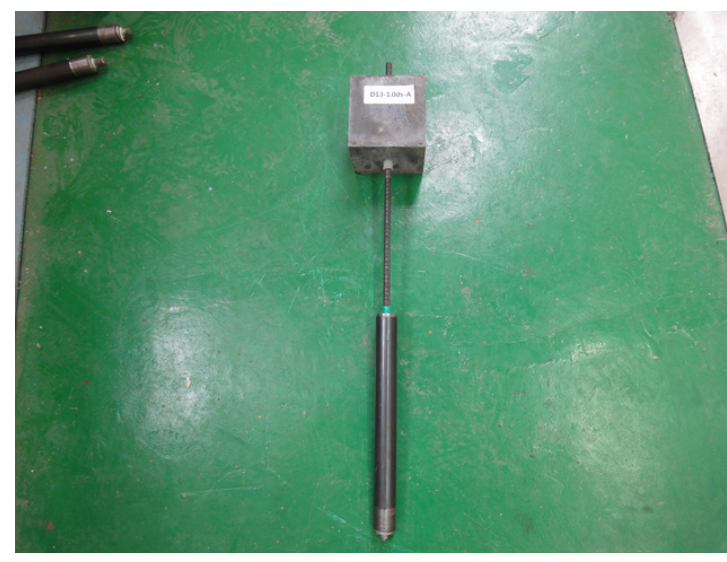

(b) Cylinder grip of non-shrinkage mortar grouting

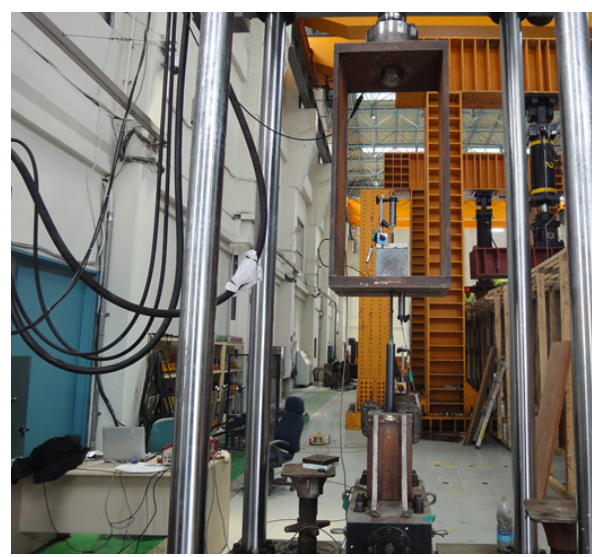

(d) Pull-out test

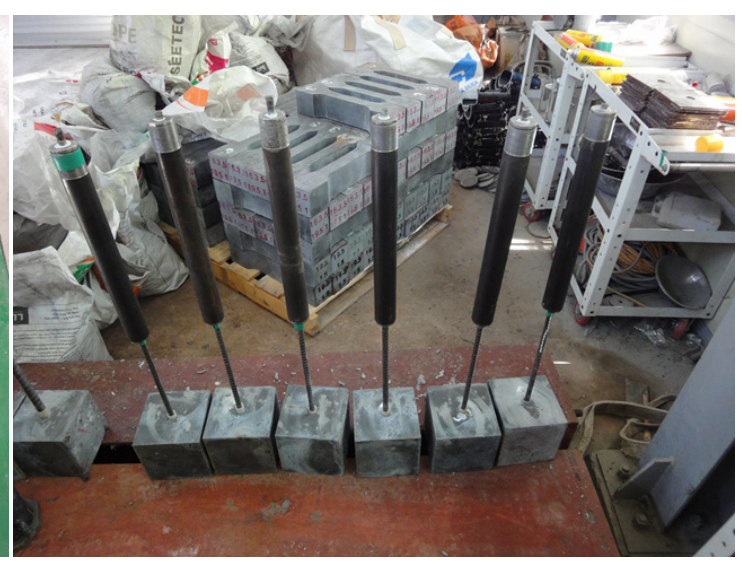

(c) Manufacture of specimens
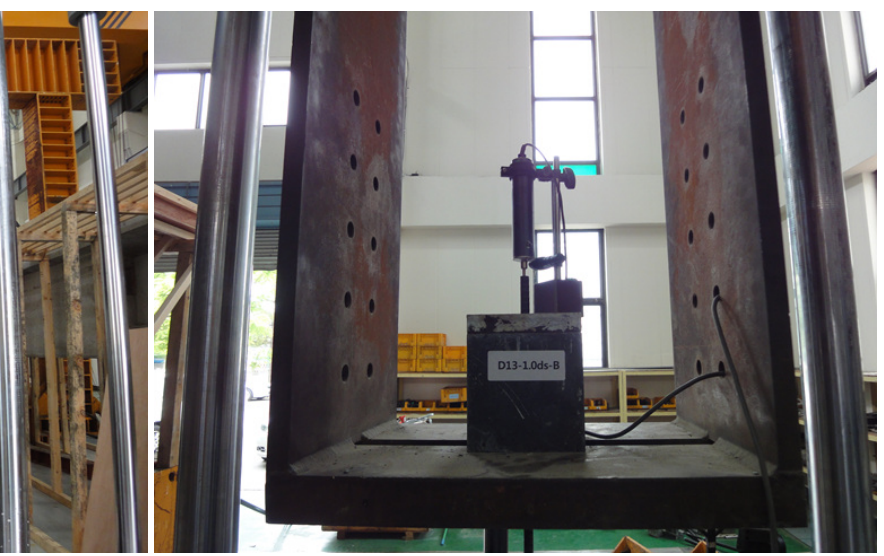

(e) Measurement of steel slip

Figure 2. Example Pull-out test of bond behavior analysis of deformed bar.

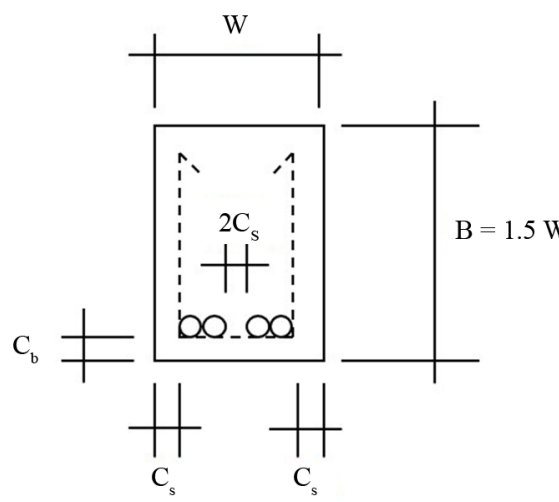

(a) Cross-sectional dimensions

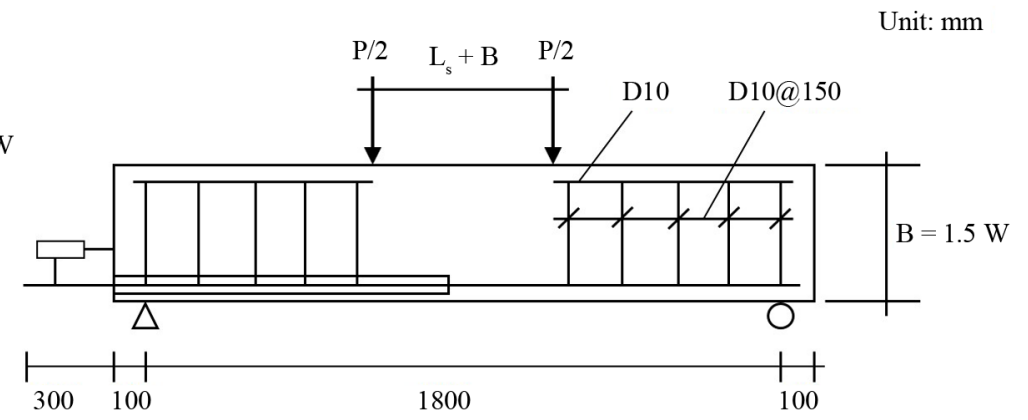

(b) Front view 


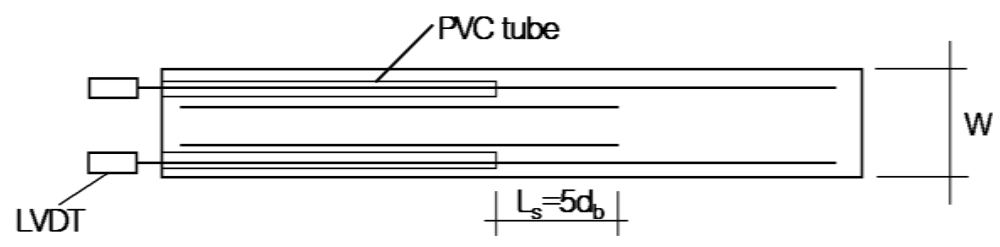

(c) Plan view

Figure 3. Details of flexural specimens.

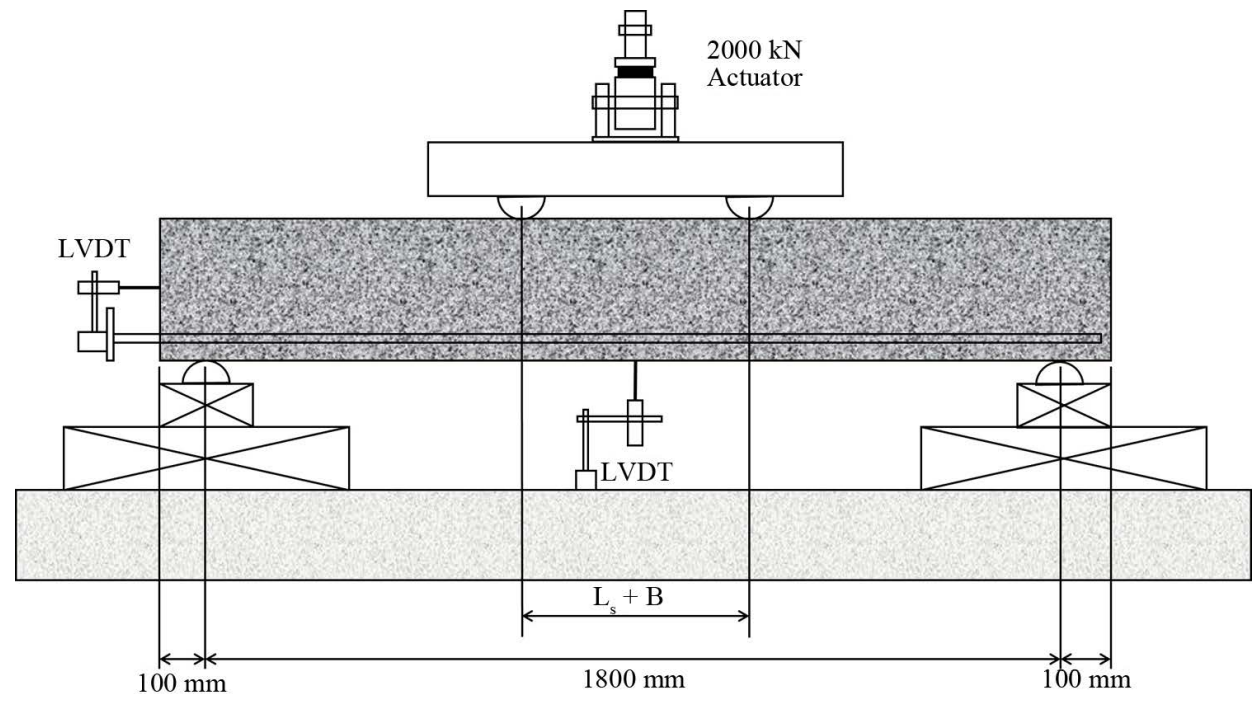

Figure 4. Detailed setting of flexural test.

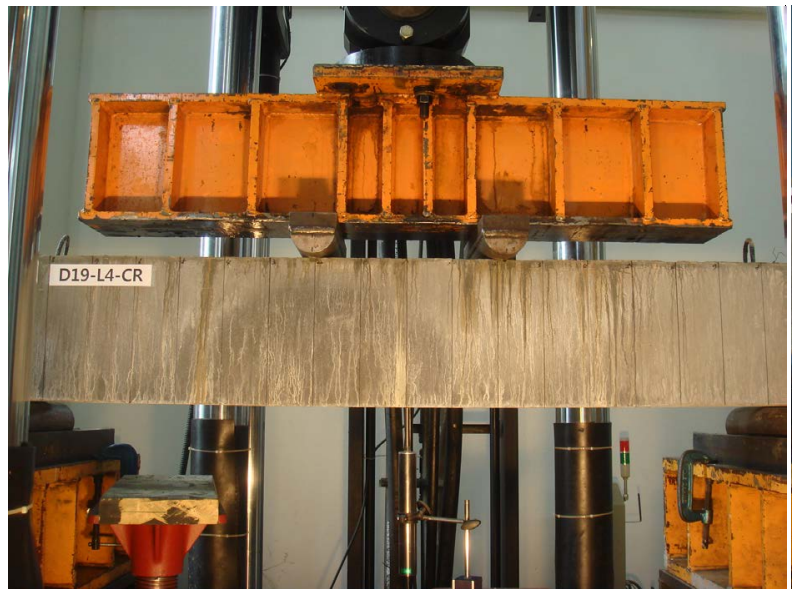

(a) Before flexural strength test

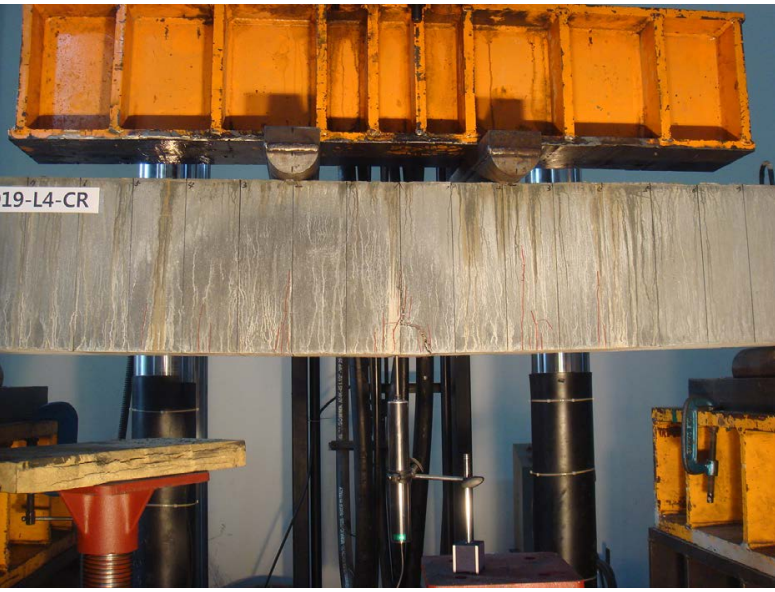

(b) After flexural strength test

Figure 5. Photo of flexural strength test.

In view of the bond test results, nearly all of the specimens with bond length 3 times the rebar diameter ( $\left.3 d_{s}\right)$ experienced yielding of the rebar first without bond failure. The specimens with bond length of $2 d_{s}$ also experienced yielding of a part of their reinforcing bars. Bond slip occurred and failure progressed in the case where the bond length was equal to the rebar diameter. The increase of the bond length from $1 d_{s}$ to $2 d_{s}$ resulted in the significant increase of the maximum load but the increase of the bond length to $3 d_{s}$ did not provide noteworthy difference in the maximum load.

The bond stress tended to reduce with larger rebar diameter. The largest bond stress was developed in the D13 rebar for the bond length of $1 d_{s}$ while similar results were observed for the other cases. This indicates that 
Table 4. Pull-out test results.

\begin{tabular}{|c|c|c|c|c|c|}
\hline Steel rebar & $\begin{array}{l}\text { Bond length } \\
\text { (mm) }\end{array}$ & $\begin{array}{c}\text { Concrete } \\
\text { cover }(\mathrm{mm})\end{array}$ & $\begin{array}{l}\text { Max. load } \\
(\mathrm{kN})\end{array}$ & $\begin{array}{l}\text { Bond stress } \\
(\mathrm{MPa})\end{array}$ & $\begin{array}{l}\text { Rebar stress } \\
\text { (MPa) }\end{array}$ \\
\hline \multirow{7}{*}{ D10 } & 9.5 & 9.5 & 20.7 & 72.9 & 292 \\
\hline & 9.5 & 19 & 21.3 & 75 & 300.5 \\
\hline & 9.5 & 45 & 21.6 & 76.2 & 304.7 \\
\hline & 19 & 19 & 41 & 72.3 & 578.4 \\
\hline & 28.5 & 9.5 & 42.3 & 49.7 & 596.8 \\
\hline & 28.5 & 19 & 41.2 & 48.4 & 581.2 \\
\hline & 28.5 & 45 & 44.4 & 52.2 & 626.4 \\
\hline \multirow{10}{*}{ D13 } & 12.7 & 12.7 & 39.7 & 78.4 & 313.4 \\
\hline & 12.7 & 25.4 & 51.8 & 102.2 & 408.9 \\
\hline & 12.7 & 69 & 46.9 & 92.5 & 370.2 \\
\hline & 19.05 & 69 & 39.8 & 52.3 & 314.1 \\
\hline & 25.4 & 69 & 39.9 & 39.3 & 314.9 \\
\hline & 25.4 & 69 & 46.2 & 45.6 & 364.7 \\
\hline & 25.4 & 25.4 & 69.1 & 72.6 & 545.5 \\
\hline & 38.1 & 12.7 & 67.6 & 44.5 & 533.6 \\
\hline & 38.1 & 25.4 & 71 & 46.7 & 560.5 \\
\hline & 38.1 & 69 & 68.4 & 45 & 540 \\
\hline \multirow{7}{*}{ D16 } & 15.9 & 15.9 & 36.1 & 45.4 & 181.8 \\
\hline & 15.9 & 31.8 & 50.7 & 63.8 & 255.3 \\
\hline & 15.9 & 67 & 56 & 70.5 & 282 \\
\hline & 31.8 & 31.8 & 100.4 & 63.2 & 505.6 \\
\hline & 47.7 & 15.9 & 109.1 & 45.8 & 549.5 \\
\hline & 47.7 & 31.8 & 111.6 & 47 & 562.1 \\
\hline & 47.7 & 67 & 116.3 & 48.8 & 585.7 \\
\hline \multirow{13}{*}{ D19 } & 19.1 & 19.1 & 82.7 & 72.1 & 288.6 \\
\hline & 19.1 & 38.2 & 102 & 89.4 & 356 \\
\hline & 19.1 & 65.5 & 66.1 & 57.7 & 212.6 \\
\hline & 19.1 & 65.5 & 86.36 & 75.4 & 277.8 \\
\hline & 19.1 & 90 & 99.8 & 87.1 & 348.3 \\
\hline & 28.65 & 65.5 & 116.4 & 67.7 & 374.4 \\
\hline & 28.65 & 65.5 & 108.6 & 63.1 & 349.2 \\
\hline & 38.2 & 38.1 & 140 & 60.9 & 488.6 \\
\hline & 38.2 & 65.5 & 132.5 & 57.8 & 426.1 \\
\hline & 38.2 & 65.5 & 131.1 & 57.2 & 421.7 \\
\hline & 57.3 & 19.1 & 60.4 & 17.6 & 210.8 \\
\hline & 57.3 & 38.2 & 146.2 & 42.5 & 510.3 \\
\hline & 57.3 & 90 & 150 & 43.6 & 523.5 \\
\hline \multirow{6}{*}{ D22 } & 22.2 & 22.2 & 87.5 & 56.3 & 226.1 \\
\hline & 22.2 & 44.4 & 104.6 & 67.1 & 270.2 \\
\hline & 22.2 & 89 & 121.2 & 78.2 & 313.1 \\
\hline & 44.4 & 44.4 & 173.7 & 56.8 & 448.7 \\
\hline & 66.6 & 22.2 & 168.5 & 36.3 & 435.3 \\
\hline & 66.6 & 44.4 & 206.4 & 44.5 & 533.2 \\
\hline
\end{tabular}

smaller rebar diameter is favorable for the development of the bond stress but without noticeable difference. For the specimens with relatively thinner cover depth, the results showed large variation in the specimens with the same variables. The results showed that the expected improvement of the performance could not be achieved when the cover depth was not completely secured even if the lap-splice length was increased.

\subsection{Effect of Lap-Splice Length of UHPC Flexural Members}

Table 5 arranges the results of the flexural tensile test of UHPC. Figure 6 plots the load-displacement curves for the evaluation of the effect of the lap-splice length in the UHPC flexural members. The deflection curves are drawn by defining the maximum deflection as the deflection at $85 \%$ of the critical load. Figure 7 compares the lap splice lengths enabling to achieve the performance of the rebar in UHPC.

Apart from specimen CR with cover depth 1.5 times the rebar diameter, all the specimens with rebar D13 showed stable performance by resisting to slightly larger maximum load as much as the lap-splice length was 


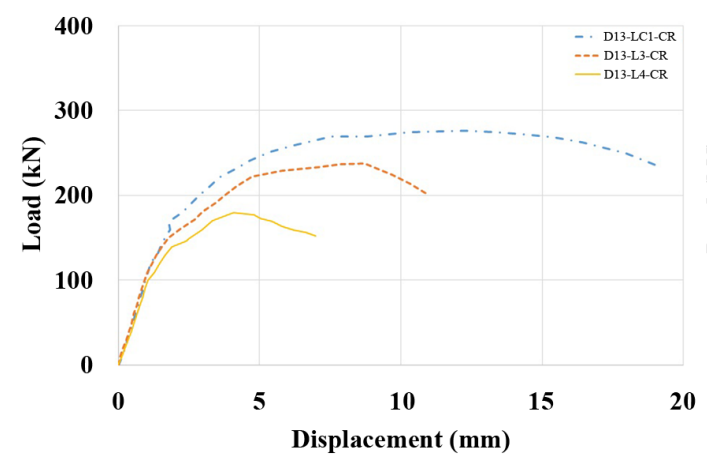

(a) Cover depth $=1.5 \quad d_{b}$ (D13)

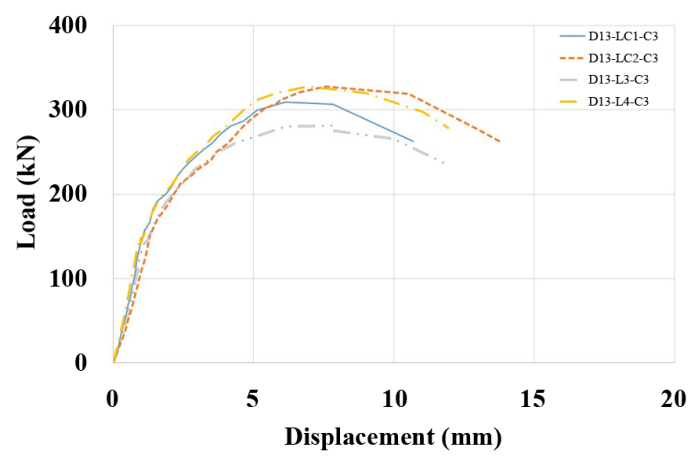

(c) Cover depth $=3.0 \quad d_{b}$ (D13)

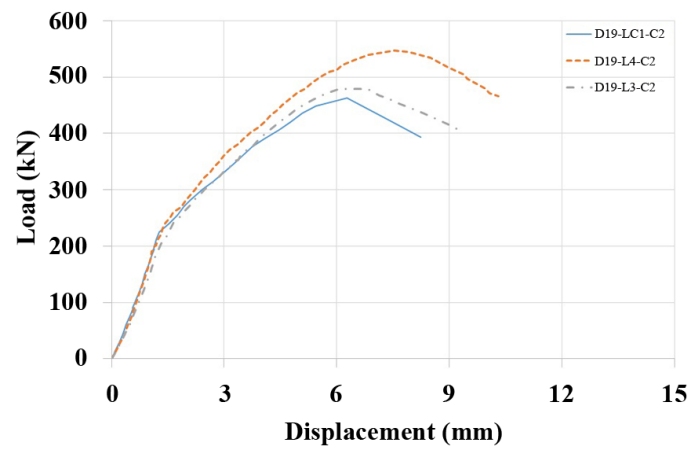

(e) Cover depth $=2.0 \quad d_{b}$ (D19)

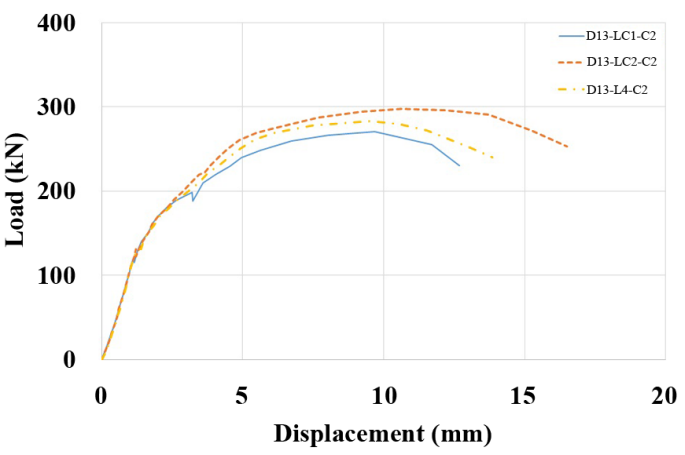

(b) Cover depth $=2.0 \quad d_{b}$ (D13)

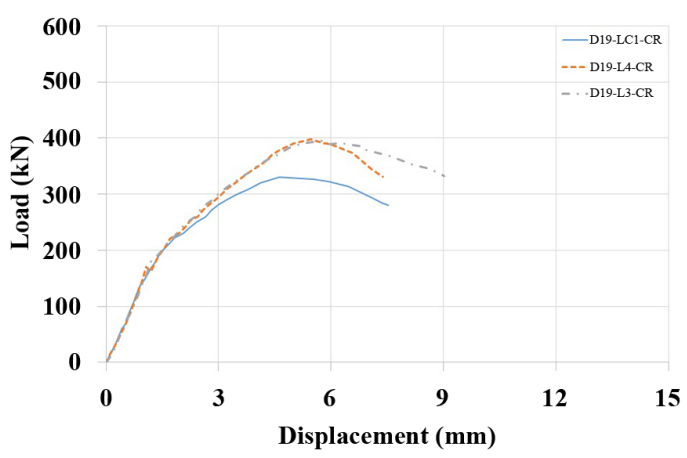

(b) Cover depth $=1.5 \quad d_{b}$ (D19)

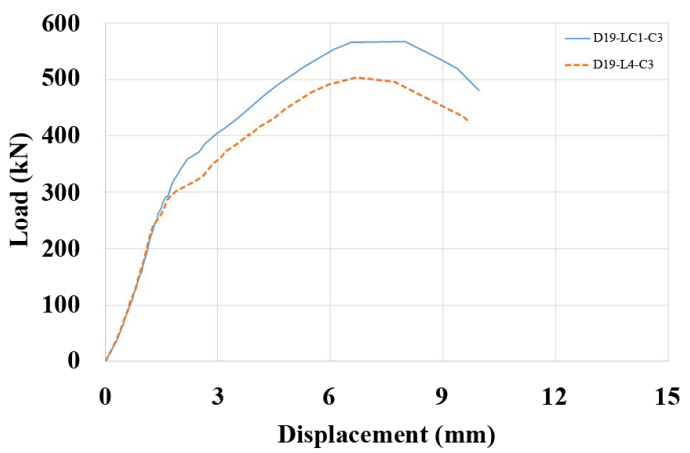

(f) Cover depth $=3.0 \quad d_{b}$ (D19)

Figure 6. Load-displacement curves considering cover depth.

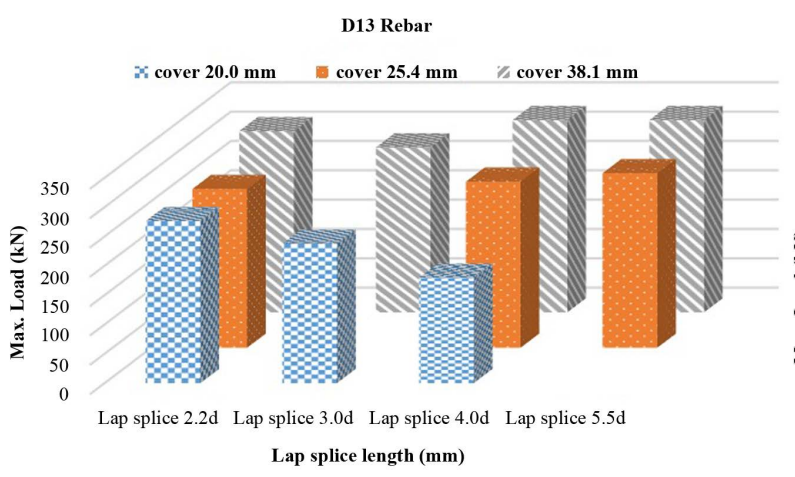

(a) Specimens reinforced with D13 bars

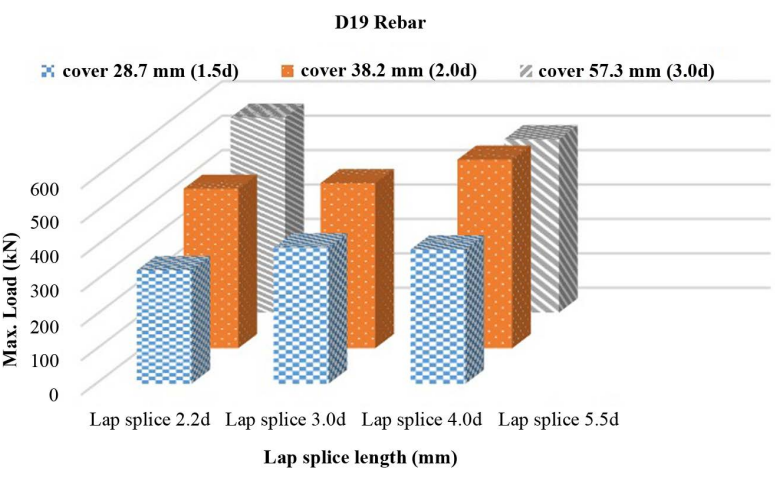

(b) Specimens reinforced with D19 bars

Figure 7. Variation of maximum vertical load according to lap-splice change per cover depth. 
Table 5. Flexural test results.

\begin{tabular}{cccccc}
\hline & \multicolumn{3}{c}{ Test results } \\
& \multicolumn{7}{c}{ Case } & $P_{\max }(\mathrm{kN})$ & $\Delta_{y}(\mathrm{~mm})$ & $\Delta_{\max }(\mathrm{mm})$ & Slip $(\mathrm{mm})$ & Failure mode \\
\cline { 2 - 5 } D13-L3-CR & 236.5 & 87.1 & 13.52 & 5.94 & Flexure \\
D13-L4-CR & 179.6 & 4.07 & 9.58 & 4.34 & Flexure \\
D13-LC1-CR & 276.3 & 12.29 & 22.95 & 5.22 & Flexure \\
D13-L4-C2 & 283.2 & 9.51 & 17.64 & 7.47 & Flexure \\
D13-LC2-C2 & 297.7 & 10.65 & 20.34 & 9.73 & Flexure \\
D13-LC1-C2 & 270.6 & 9.69 & 17.24 & 7.99 & Flexure \\
D13-L3-C3 & 159.5 & 7.88 & 18.04 & 1.13 & Flexure \\
D13-L4-C3 & 169.5 & 6.93 & 19.41 & 1.84 & Flexure \\
D13-LC2-C3 & 191.3 & 7.55 & 18.09 & 1.76 & Flexure \\
D13-LC1-C3 & 174.8 & 6.13 & 21.24 & 7.82 & Flexure \\
D19-L3-CR & 391.4 & 6.25 & 11.99 & 5.52 & Flexure \\
D19-L4-CR & 390.3 & 5.91 & 10.64 & 4.71 & Flexure \\
D19-LC1-CR & 329.9 & 4.61 & 10.47 & 4.95 & Flexure \\
D19-L3-C2 & 479.4 & 6.82 & 12.55 & 5.54 & Flexure \\
D19-L4-C2 & 547.8 & 7.53 & 15.50 & 6.35 & Flexure \\
D19-LC1-C2 & 463.1 & 6.27 & 12.16 & 5.09 & Flexure \\
D19-L4-C3 & 503.6 & 6.69 & 14.04 & 5.96 & Flexure \\
D19-LC1-C3 & 566.5 & 7.98 & 12.36 & 5.06 & Flexure \\
\hline
\end{tabular}

longer but without noticeable difference. This indicates that sufficient performance can be achieved even with the lap-splice length corresponding to 2.2 times the rebar diameter as derived from the results of the pull-out test in Section 3.1.

The minimum lap-splice length corresponding to 5.5 times the rebar diameter prescribed by the current UHPC Structure Design Guideline appears to provide sufficient safety margin of $250 \%$ compared to the case with 2.2 times the rebar diameter derived from the test results. Besides, compared to D19-specimens applying a minimum cover depth of $28.7 \mathrm{~mm}$, the D13-specimens with cover depth of $20 \mathrm{~mm}$ exhibit unstable performance without consistency in the change of the maximum resisting load even when the lap-splice length is enlarged. This indicates that even if the minimum lap-splice length is prescribed to provide sufficient safety margin, the minimum cover depth corresponding to 1.5 times the rebar diameter in the case of small rebar diameter fails to achieve satisfactory flexural performance.

\subsection{Effect of Cover Depth of UHPC Flexural Members}

Figure 8 plots the load-displacement curves for evaluating the effect of the cover depth in the UHPC flexural members. The deflection curves are drawn with respect to the load and by defining the maximum displacement as the deflection corresponding to $85 \%$ of the final value. In view of the load-displacement curves of the specimens exhibiting different cover depths, it appears that the load bearing capacity and the ductility capacity improve with larger cover depth.

Figure 9 compares the minimum cover depths enabling to achieve the performance of the rebar in UHPC. Recall that CR designates the specimen with cover depth 1.5 times the rebar diameter corresponding to the minimum cover depth specified in the current UHPC Structure Design Guideline, and that C2 and C3 represent respectively the specimens with cover depth 2.0 times and 3.0 times the rebar diameter. The comparison of the results reveals that the load bearing capacity and ductile capacity start to converge from specimens C2 to show clearly stable behavior of the flexural members. Specimens C3 do not exhibit significant improvement of the load bearing capacity and ductile capacity compared to the increase of the cover depth.

In view of the comparison between the specimens reinforced by D13 bars with cover depth of $20 \mathrm{~mm}$ and the specimens reinforced by D19 bars with cover depth of 28.7 corresponding to 1.5 times of rebar diameter according to the current UHPC Structure Design Guideline (maximum value between 1.5 times of rebar diameter and $20 \mathrm{~mm}$ ), the D13-specimens with the smaller absolute value of the cover depth fail to develop stable behavior even if they secure sufficient lap-splice length. Besides, the D19-specimens exhibit stable behavior compared to the D13-specimens even if they apply a cover depth corresponding to 1.5 times of rebar diameter as specified in the current UHPC Structure Design Guideline. This indicates that the stability of the structural behavior 


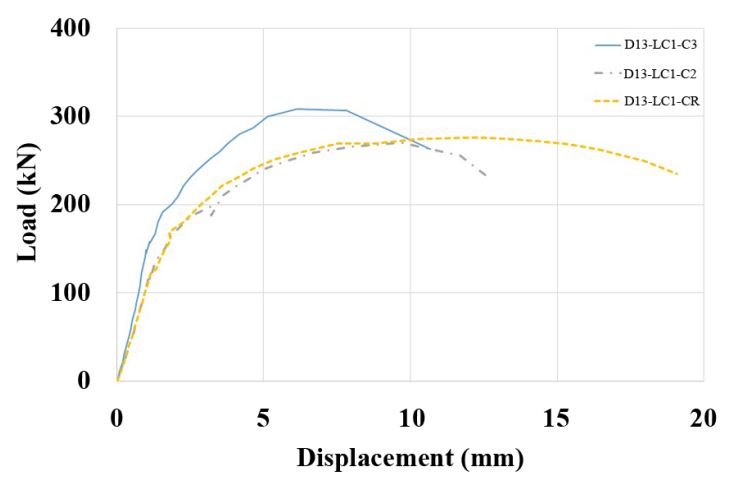

(a) Spliced length $=2.2 \quad d_{b}$ (D13)

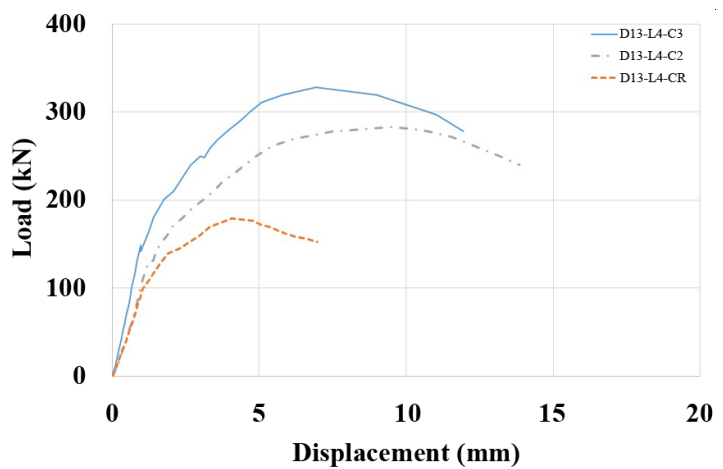

(c) Spliced length $=4.0 \quad d_{b}$ (D13)

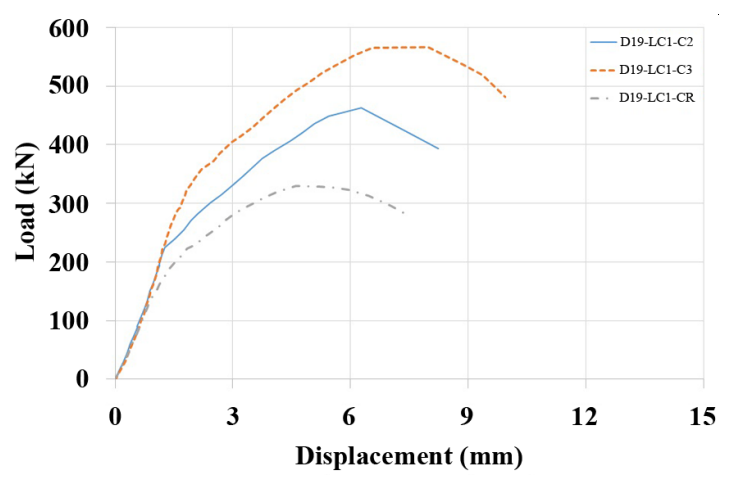

(e) Spliced length $=2.2 d_{b}$ (D19)

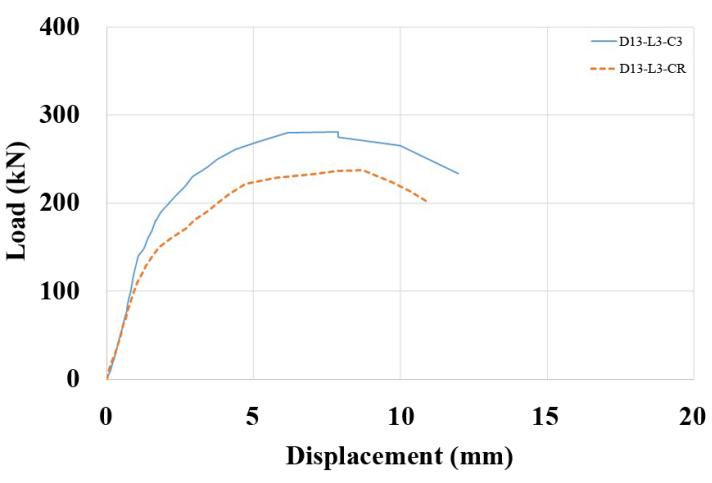

(b) Spliced length $=3.0 \quad d_{b}$ (D13)

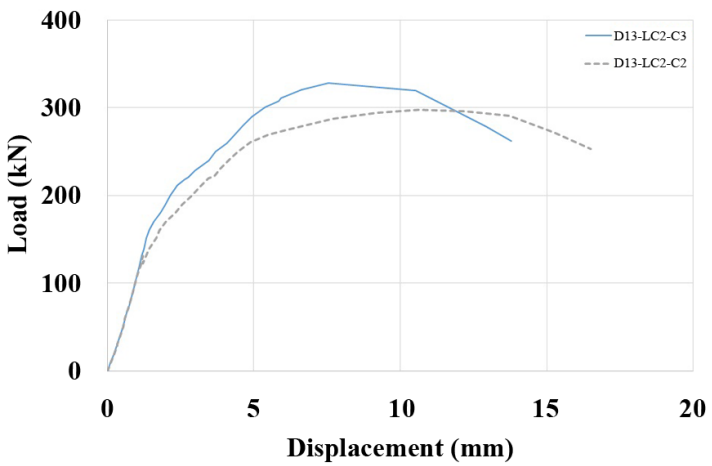

(d) Spliced length $=5.5 \quad d_{b}$ (D13)

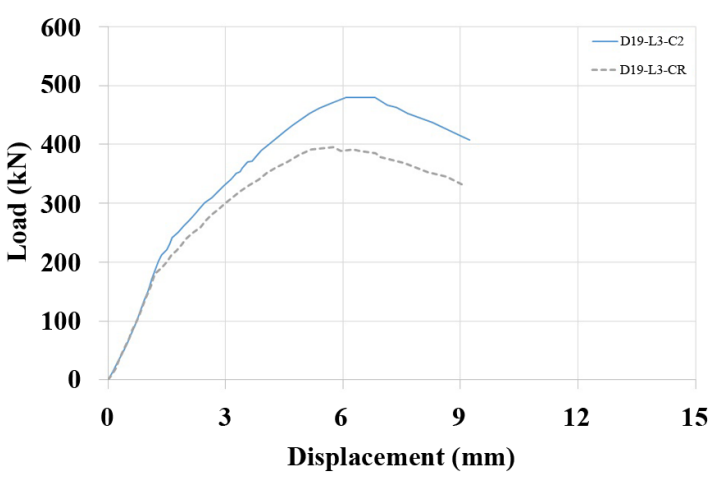

(f) Spliced length $=3.0 \quad d_{b}$ (D19)

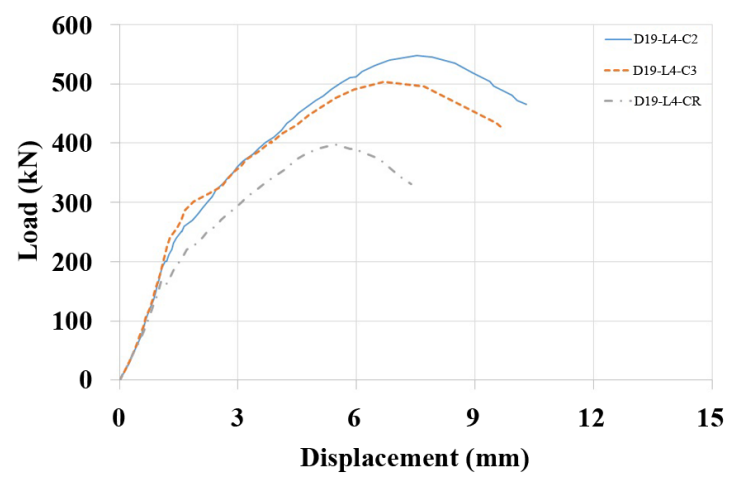

(g) Spliced length $=4.0 \quad d_{b}$ (D19)

Figure 8. Load-displacement curves considering lap-splice length. 


\section{D13 Rebar}

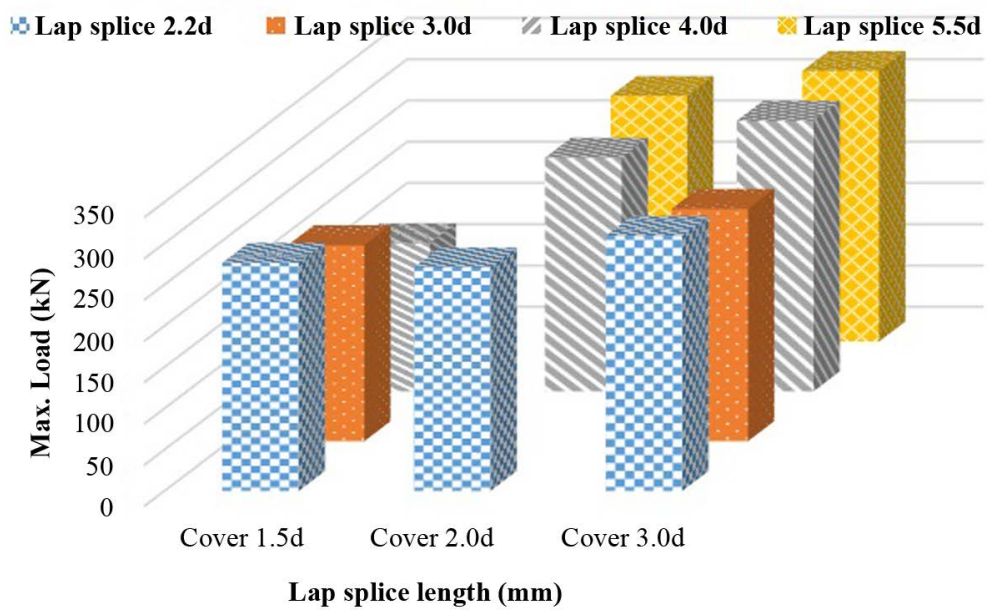

(a) Specimens reinforced with D13 bars

D19 Rebar

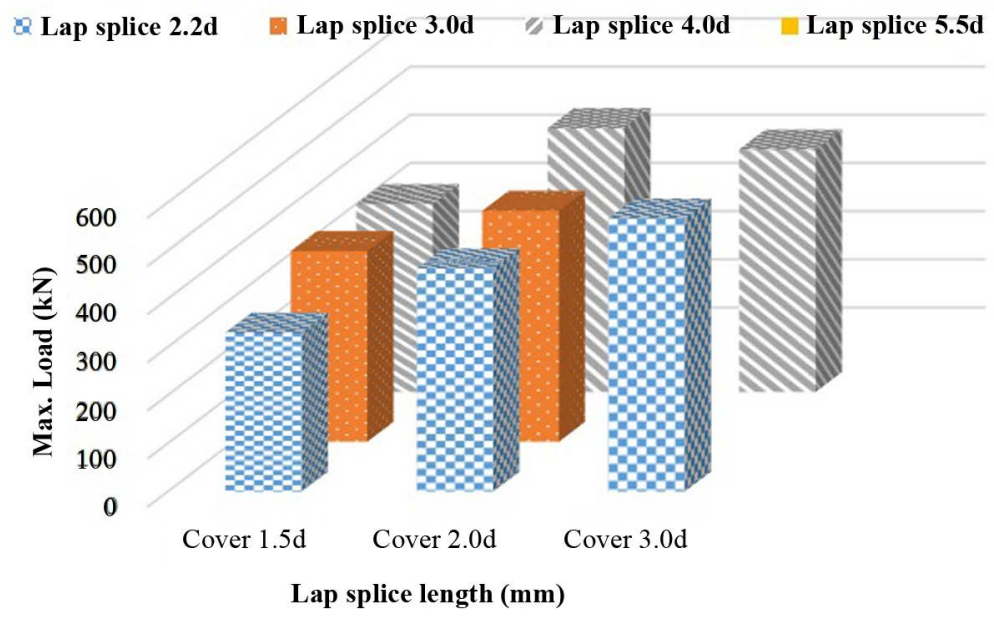

(b) Specimens reinforced with D19 bars

Figure 9. Variation of maximum vertical load according to cover depth change per lap-splice length.

can be significantly enhanced by increasing slightly the cover depth specification of the current UHPC Structure Design Guideline from the maximum value between 1.5 times of rebar diameter and $20 \mathrm{~mm}$ to the maximum value between 1.5 times of rebar diameter and $25 \mathrm{~mm}$.

\section{Conclusions}

This study conducted pull-out test and flexural bond performance test taking the rebar diameter, the concrete cover depth and the lap-splice length as main test variables in order to evaluate the bond characteristics in 180-MPa UHPC flexural members considering the lap-splice length and cover depth. The following conclusions can be drawn.

1) The minimum lap-splice length evaluated in the pull-out test averages about 1.85 times the rebar diameter when neglecting the margin. This represents approximately $1 / 8$ of the lap-splice length provided by the design formula for ordinary concrete that does not consider the characteristics of UHPC and means that the lap-splice length can be reduced significantly.

2) Considering the minimum lap-splice length evaluated in the pull-out test, the lap-splice length was increased to 2.2, 3.0, 4.0 and 5.5 times the rebar diameter in the flexural members. The results showed that the 
expected improvement of the performance could not be achieved when the cover depth was not completely secured even if the lap-splice length was increased.

3) When the cover depth was secured, stable load bearing capacity and ductile capacity could be secured even with the minimum lap-splice length corresponding to 2.2 times the rebar diameter. The lap-splice length corresponding to 5.5 times the rebar diameter proposed in the current UHPC Structure Design Guideline was seen to provide a margin of $250 \%$ compared to the length of 2.2 times the rebar diameter and to secure sufficient safety as well as to offer a rational value reflecting the outstanding characteristics of UHPC.

4) In case of small rebar diameter like D10 or D13 in the K-UHPC structure, a value of $20 \mathrm{~mm}$ is prescribed for the minimum cover depth. However, in view of the experimental results, it seemed recommendable to increase slightly this value. Besides, in case of large rebar diameter like D19, stable performance could be achieved even with a minimum cover depth of $28.8 \mathrm{~mm}$ corresponding to 1.5 times the rebar diameter. Accordingly, the stability of the structural behavior can be significantly enhanced by increasing slightly the cover depth specification of the current UHPC Structure Design Guideline from the maximum value between 1.5 times of rebar diameter and $20 \mathrm{~mm}$ to the maximum value between 1.5 times of rebar diameter and $25 \mathrm{~mm}$.

\section{Acknowledgements}

This research was supported by a grant (15 AUDP-B069632-03) from Urban Architectural Research Program funded by Ministry of Land, Infrastructure and Transport of Korean Government.

\section{References}

[1] Ministry of Land, Transport and Maritime Affairs of Korea and Korea Concrete Institute (2012) Structural Concrete Design Code.

[2] Korea Institute of Civil Engineering and Building Technology (2011) Design Technology for Ultra High Performance Concrete, Super Bridge 200, 5th Report.

[3] Kook, K.H., Shin, H.O., Kwahk, I. and Yoon, Y.S. (2010) Bond Characteristics of Ultra High Performance Concrete. Journal of the Korea Concrete Institute, 22, 753-760. http://dx.doi.org/10.4334/JKCI.2010.22.6.753

[4] Kwahk, I., Joh, C. and Lee, J. (2015) Torsional Behavior Design of UHPC Box Beams Based on Thin-Walled Tube Theory. Engineering, 7, 101-114. http://dx.doi.org/10.4236/eng.2015.73009

[5] Fehling, E. and Leutbecher, T. (2007) Tensile Behavior of Ultra High Performance Concrete (UHPC) Reinforced with a Combination of Steel-Fibers and Rebars. Proceedings of 3rd International Conference on Structural Engineering Mechanics and Computation (SEMC), Cape Town, 10-12 September 2007, 549-550.

[6] Jungwirth, J. (2006) Zum Zugtragverhalten von zugbeanspruchten Bauteilenaus Ultra-Hochleistungs-Faserbeton. Thesis No. 3429, Faculté Environnement Naturel, Architectural et Construit, Ecole Polytechnique Fédérale de Lausanne, Lausanne.

[7] Korea Concrete Institute (2012) Design Guidelines for K-UHPC, KCI-M-12-003.

[8] Yang, J.H., Kim, W. and Lee, G.Y. (2009) Crack Width Calculation Based on Bond Characteristics and Cracking Behavior of Reinforced Concrete Structures. Journal of the Korean Society for Railway, 12, 944-952.

[9] Kim, W., Lee, K.Y. and Kim, J.H. (2006) Evaluation of Crack Width Based on the Actual Bond Stress-Slip Relationship in Structural Concrete Members. Journal of the Korea Concrete Institute, 18, 91-100. http://dx.doi.org/10.4334/JKCI.2006.18.1.091

[10] Lee, G.Y., Ha, T.G. and Kim, W. (2007) Modeling of Tension Stiffening Effect Based on Nonlinear Bond Characteristics in Structural Concrete Members. Journal of the Korea Concrete Institute, 19, 745-754. http://dx.doi.org/10.4334/JKCI.2007.19.6.745

[11] Choi, S.W., Yang, J.H. and Kim, W. (2010) Influence of Tension Stiffening Effect on Deflection and Crack Width in RC Members. Journal of the Korea Concrete Institute, 22, 761-768. http://dx.doi.org/10.4334/JKCI.2010.22.6.761

[12] Ciampi, V., Eligehausen, R., Bertero, V.V. and Popov, E.P. (1982) Analytical Model for Concrete Anchorages of Reinforcing Bars under Generalized Excitations, Report No. EERC82-83, Earthquake Engineering Research Center, University of California, Berkeley.

[13] Tue, N.V. and König, G. (1992) Calculating the Mean Bond and Steel Stress in Reinforced and Prestressed Concrete Members, Darmstadt Concrete, 6.

[14] Kwahk, I., Lee, J.W., Joh, C. and Kim, B.S. (2011) Crack Width Evaluation of K-UHPC by Direct Tensile Test. Journal of the Korea Concrete Institute, 23, 183-184. 
[15] Pyfl, T. (2003) Tragverhalten von Stahlfaserbeton, Dissertation ETH Nr. 15005, ETH, Zurich.

[16] Japan Society of Civil Engineering (2004) Recommendations for Design and Construction of Ultra High Strength Fiber Reinforced Concrete Structures, Draft, Concrete Library 113.

[17] Ko, W.J., Min, B.C. and Park, S.K. (2006) The Estimation and Comparison of Flexural Crack Width Considering Bonding Characteristics in Reinforced Concrete Members. Journal of the Korea Concrete Institute, 18, 579-588. http://dx.doi.org/10.4334/JKCI.2006.18.5.579

[18] Lee, G.Y. and Kim, W. (2008) Analysis of Crack Width and Deflection Based on Nonlinear Bond Characteristics in Reinforced Concrete Flexural Members. Journal of the Korea Concrete Institute, 20, 459-467. http://dx.doi.org/10.4334/JKCI.2008.20.4.459

[19] Jung, J.H., Kang, H., Ahn, J.M. and Shin, S.W. (2008) Bond Stress between Reinforcement and Ultra High-Strength Concrete with a Compressive Strength of $150 \mathrm{MPa}$. Journal of the Architectural Institute of Korea Structure \& Construction, 24, 43-50.

[20] Lee, G.Y., Kim, W. and Lee, H.M. (2009) Tension Lap Splice Length in High-Strength Concrete Flexural Members. Journal of the Korea Concrete Institute, 21, 753-761. http://dx.doi.org/10.4334/JKCI.2009.21.6.753

[21] RILEM (1970) Technical Recommendations for the Testing and Use of Construction Materials, RC 6, Bond Test for Reinforcement Steel. 2. Pull-Out Test. 